\title{
Evaluation of Carcass and Non-carcass Characteristics of West African Dwarf Rams Fed Bambusa vulgaris Leaves with Neem Seed Cake and Guinea Grass \\ *M. I. Okoruwa, Okoh, P. I. and Ikhimioya, I. \\ Department of Animal Science, Ambrose Alli University \\ P.M.B 14, Ekpoma, Nigeria. \\ *Correspondence author e-mail; odionokos@yahoo.com, \\ Abstract okosmich@gmail.com
}

Eighteen West African Dwarf rams balanced for weight ( $8.00 \pm 0.20 \mathrm{~kg})$ were fed with Bambusa vulgaris leaves with neem seed cake and guinea grass to evaluate their carcass and non-carcass characteristics. The rams were assigned to three dietary treatments in a completely randomized design with six rams per treatment. The compared dietary treatments were as follows. Diet A(70\% guinea grass and $30 \%$ concentrate diet); diet B (mixture of $50 \%$ Bambusa vulgaris leaves with $20 \%$ neem seed cake and $30 \%$ concentrate diet) and diet C(combination of $45 \%$ Bambusa vulgaris leaves with $25 \%$ neem seed and $30 \%$ concentrate diet). The results showed that diet $A$ was significantly $(P<0.05)$ higher in average total feed intake (11.13kg), chilling losses (15.04\%) and rumen / reticulum (2.04\%) than diets B and C. Slaughter weight $(11.33 \mathrm{~kg})$, empty body weight $(10.32 \mathrm{~kg})$, hot and cold carcass weights $(6.01 \& 5.54 \mathrm{~kg})$, hot and cold carcass yield $(53.05 \& 48.90 \%)$, true yield $(58.24 \%)$, liver $(2.01 \%)$, kidneys $(1.12 \%)$ and lungs $(1.35 \%)$ were significantly $(P<0.05)$ higher in diet $B$ than diet $A$ or $C$. No significant difference $(P>0.05)$ observed in initial body weight, heart, spleen, omasum, abomasums, blood, skin and head among the treatment diets. It could be concluded that mixture of 50\% Bambusa vulgaris leaves with $20 \%$ neem seed cake and $30 \%$ concentrate diet has the potential to improve carcass and non-carcass characteristics of West African Dwarf rams.

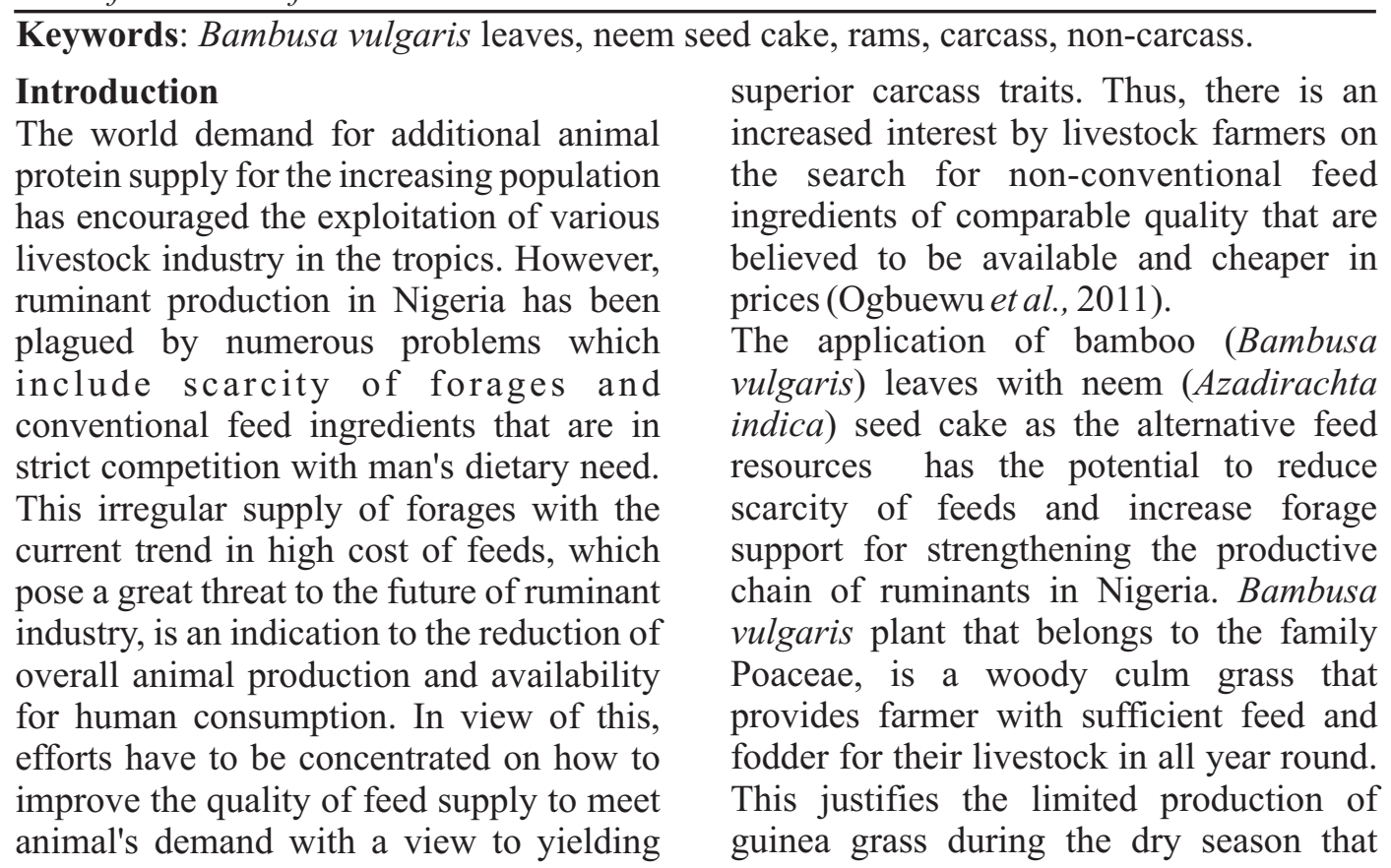


brings about loss of weight in sheep production. It has been reported that Bambusa vulgaris leaves are rich in some nutrients most especially protein, phosphorus and carotene which are the principal components that may be limiting in plant on rangeland (Zehui, 2007). AntwiBoasiako et al. (2011) also noticed that feeding Bambusa vulgaris leaves alone to ruminants may not yield much benefit, if not supplement with other feeds. Hence, neem seed cake was added to augment the nutrients that will be supply by Bambusa vulgaris. Neem seed cake is a by - product of neem oil industry. It has been widely used as an alternative animal feedstuff because of its nutritional potentials. However, its use as feedstuff is limited due to the pungent smell and bitter taste imparted by the presence of toxic titerpenoids which are mainly nimbin, nimbidin, azadirachtin and salanin (Bawa et al., 2006). Previous studies (Gowds and sastry, 2000) indicated that feeding of neem seed to livestock reduce intake, feed utilization and impart unpleasant taste or smell on the meat. Thus, detoxification and reduction of bitterness for palatability enhancement in neem seed meal is important.

Carcass yield is important in the evaluation of animal production because, it is directly related to the commercial value of the animal being usually one of the first indexes to be considered. It is expressed as the percentage ratio between the carcass weight and live animal weight (Casey and Webb, 2010). The proper conformation of the carcass indicates a proportional development of the different anatomical regions and the best conformation are achieved when the parts with greatest commercial value are well pronounced (Maciel et al., 2015). These objective measures can be used to evaluate the characteristics of a carcass (Skapetas et al.,
2006) and estimating the carcass characteristics is important to complement the evaluation of the animal's performance during its development. Moreover, comprehensive reports on carcass and noncarcass traits of rams fed Bambusa vulgaris leaves with neem seed cake and guinea grass are relatively scarce and such information is vital to provide a broad picture of the probable effect of meat products.

Hence, the objective of this study was to evaluate carcass and non-carcass characteristics of West African Dwarf rams fed Bambusa vulgaris leaves with neem seed cake and guinea grass.

\section{Materials and Methods Experimental site}

The experiment was conducted at the Sheep and Goat Unit of the Teaching and Research Farm, Ambrose Alli University, Ekpoma, Nigeria. The location has prevailing tropical climate with mean rainfall and temperature of about $1556 \mathrm{~mm}$ and $31^{\circ} \mathrm{C}$ respectively. Ekpoma is within the southsouth geo-political zone of Nigeria. The vegetation represents an interface between the tropical rainfall and derived savanna.

\section{Experimental diets}

The neem seeds were collected during fruiting season in their producing areas around Auchi in Edo - State. The neem fruits were soaked in water for five days and depulped using depulper machine. Thereafter, seeds and pulp were washed and sundried for ten days. Dried seeds were decorticated, crushed, steamed before the oil was pressed out using expeller machine to obtain neem seed cake. Guinea grass and Bambusa vulgaris leaves were obtained within the livestock farm of the Ambrose Alli University, Ekpoma. However, Bambusa vulgaris leaves with neem seed cake and guinea grass constituted the diets. 


\section{Okoruwa, Okoh and Ikhimioya}

The concentrate diet that was added to the dietary treatments, consisted of $80 \%$ wheat offal, $18 \%$ dried brewery grain, $0.75 \%$ oyster shell, $0.5 \%$ bone meal, $0.5 \%$ salt and $0.25 \%$ vitamin premix.

Three treatment diets were prepared, which composed of A ( $70 \%$ guinea grass and $30 \%$ concentrate diet), B (mixture of $50 \%$ Bambusa vulgaris leaves with $20 \%$ neem seed cake and $30 \%$ concentrate diet) and $\mathrm{C}$ (combination of $45 \%$ Bambusa vulgaris leaves with $25 \%$ neem seed and 30\% concentrate diet)

\section{Experimental animals and design}

Eighteen West African Dwarf rams that were sourced from livestock market at Ekpoma was used for the experiment. The rams were about $8-9$ months old at the start of the experiment and had an average initial body weight of about $8.00 \pm 0.20 \mathrm{~kg}$. They were randomly distributed to the three treatment diets (A, B \& C) with replicates of six rams per treatment group in a completely randomized design.

\section{Management and feeding of the experimental animals}

Sheep pens were cleaned and disinfected before the arrival of the rams. On arrival, the rams were vaccinated against the common diseases. At the start of the experiment, rams received an oral dewormer against helminthesis and an injectable ADE vitamin complex. The rams were housed in individual dwarf wall pen of $2 \mathrm{~m} \times 2.5 \mathrm{~m}$ with cement blocks. Diets were offered at $5 \%$ of their body weight to the rams once a day at about 8.00am in form of complete mixing and ensuring the voluntary consumption. The rams had free access to water and mineral salt lick.

However, feeds offered and leftover were weighed and recorded on a daily basis prior to feeding and watering to determine daily intake. Animals were weighed on weekly basis after they were weighed at the beginning of the trial. The experiment lasted for 84days for data collection, excluding 14days for adaptation of rams to diets and handling facilities.

\section{Slaughter procedure}

After 84-days of rams' confinement on their respective experimental feeds, rams were subjected to a water diet and solid fasting for 16hours, after which rams were randomized in slaughter order. Immediately before slaughter, rams were weighed to obtain slaughter weight (SW) according to the reports of Elias et al.(2015). At slaughter, the rams were stunned by concussion, followed by bleeding out through a section of the carotid artery and jugular vein. Blood was collected and weighed. After bleeding manual skinning was performed with the help of a knife, the head was separated by the cervical vertebrae sectioning in the altanto-occipital joint. Legs were obtained by sectioning forelimbs in the carpal metacarpal joints and hind limbs tarsal metatarsal joints. Then the weight of the skin, head and limbs were recorded (Elias et al., 2015). The carcasses were eviscerated and gastrointestinal tract content was quantified by the difference between weights of full and empty gastro-intestinal tract. Thus empty body weight (EBW) was calculated by subtracting the weight of gastro - intestinal content from the SW (Skapetas et al., 2006). The hot carcass weight (HCW) was made up by the rams decapitated, bled, skinless, without viscera and extremities of limbs with kidneys and perirenal fat. Thereafter, the carcass was conducted to the cold chamber (average $4^{0} \mathrm{C}$ ) after 24 hours cooling, cold carcass weight $(\mathrm{CCW})$ was obtained and chilling losses (CL) was quantified using the formula; described by Maciel et al. (2005). $\mathrm{CL}(\%)=\frac{(\mathrm{HCW}-\mathrm{CCW})}{\mathrm{HCW}} \times \frac{100}{1}$ 
However, hot carcass yield (HCY), cold carcass yield (CCY) and true yield (TY) were calculated through the following formulas according to Urbano et al. (2013) and Maciel et al. (2015)

$$
\begin{array}{ll}
\operatorname{HCY}(\%)= & \frac{\operatorname{HCW}}{\mathrm{SW}} \times \frac{100}{1} \\
\operatorname{CCY}(\%)= & \frac{\mathrm{CCW}}{\mathrm{SW}} \times \frac{100}{1} \\
\mathrm{TY}(\%)= & \frac{\mathrm{HCW}}{\mathrm{EBW}} \times \frac{100}{1}
\end{array}
$$

The following body parameters were considered as non-carcass components: organs (heart, spleen, liver, lungs and kidneys), gut (rumen/recticulum, omasum, abomasum) and by-products (blood, skin and head). These non-carcass traits were weighed and classified in terms of their respective percentage with respect to the slaughter weight of the rams.

\section{Proximate and statistical analysis}

The proximate composition of guinea grass, Bambusa vulgaris leaves, neem seed cake and concentrate diet were analyzed according to the procedure of AOAC (1990).

Data collected from feed intake, body weights, carcass and non-carcass traits were subjected to analysis of variance (ANOVA) and significant difference between means were separated by Duncan's Multiple Range Test (SAS, 1999).

\section{Results and discussion}

Presented in Table 1, is the proximate composition of BVL, NSC, GG and CD used for the experimental diets. Dry matter content that ranged between 68.99 and $96.65 \%$ was highest in NSC and lowest in GG. The NSC had highest content of crude protein $(23.88 \%)$ and lowest content of crude fibre $(5.44 \%)$ while GG recorded the greatest amount of crude fiber $(31.00 \%)$ and smallest amount of crude protein (7.95\%). Ether extract ranged from 1.06\% for CD to 7.54 for NSC, while ash was highest in BVL (10.83\%) and lowest in NSC (5.44\%). The CD (57.16\%) contributed the highest amount of nitrogen free extract, followed by GG $(48.15 \%)$. NSC (44.55\%) before BVL (31.85). The proximate composition results for BVL and NSC in this study were similar to the values reported by Antwi-Boasiako et al. (2011) and Ogbuewu et al. (2011) respectively.

Table 1: Proximate composition (\%DM basis) of feedstuffs and concentrate diet used for the experimental diets

\begin{tabular}{lcccc}
\hline Nutrient & BVL & NSC & GG & CD \\
\hline Dry matter & 89.66 & 96.65 & 68.99 & 84.42 \\
Crude protein & 18.40 & 23.88 & 7.95 & 20.78 \\
Crude fibre & 27.06 & 5.44 & 31.00 & 13.00 \\
Ether extract & 1.52 & 7.54 & 4.00 & 1.06 \\
Ash & 10.83 & 5.44 & 8.90 & 8.00 \\
Nitrogen free extract & 31.85 & 44.55 & 48.15 & 57.16 \\
\hline BVL = Bambusa vulgaris leaves, NSC $=$ Neem seed cake, GG = Guinea grass, CD = Concentrate diet.
\end{tabular}

Table 2, shows the intake, weights and carcass traits of rams fed experimental diets. The values found for average total feed intake was similar between diets B $(10.89 \mathrm{~kg})$ and $(\mathrm{C}(10.67 \mathrm{~kg})$ but significantly $(\mathrm{P}<0.05)$ lower than diet $(\mathrm{A}$ $(11.13 \mathrm{~kg})$. The higher intake in diet A could likely be as a result of rams feeding more on guinea grass to meet their body nutrient requirement, most especially energy for their body performance. It is noteworthy that diet with high fiber concentration necessary has low energy density; hence rams fed more on diet A to meet their energy 


\section{Okoruwa, Okoh and Ikhimioya}

requirement. According to Costa et al. (2013), energy is the most limiting nutritional component in sheep production and the deficit in energy intake results in reduce animal performance with reflection on the productive indices such as carcass yield and its cuts. Slaughter weight was significantly $(\mathrm{P}<0.05)$ higher in rams on diet $\mathrm{B}(11.33 \mathrm{~kg})$ than those on diets $\mathrm{A}$ $(10.94 \mathrm{~kg})$ and $\mathrm{C}(10.81 \mathrm{~kg})$. The likely mechanism explaining this increased in slaughter weight observed in rams on diet B could probably related to the levels of protein and energy of the BVL with NSC, resulting in high nutrient utilization to all components of the ram body weight. Hence, this result might have contributed to the carcass weight by rams on this dietary treatment. Empty body weight was observed to be significantly $(\mathrm{P}<0.05)$ highest in rams on diet $\mathrm{B}(10.32 \mathrm{~kg})$ compared with diets $\mathrm{A}(9.03 \mathrm{~kg})$ and $\mathrm{C}$ $(9.60 \mathrm{~kg})$. It can be inferred that this difference obtained in empty body weight could probably due to the nutrient utilization and the weight of gastrointestinal tract contents which differ between treatment diets. However, this indicates that BVL with NSC when properly fed in appropriate proportions might become an important source of nutrients in sheep feeding, providing satisfactory performance and all round feed than guinea grass.

Table 2: Intake, weights and carcass traits of rams fed experimental diets.

\begin{tabular}{lcccc}
\hline & \multicolumn{3}{c}{ Diets } & SEM \\
\cline { 2 - 4 } Parameters & $\mathbf{A}$ & $\mathbf{B}$ & $\mathbf{C}$ & SEM \\
\hline Av. Total feed intake (kg) & $11.13^{\mathrm{a}}$ & $10.89^{\mathrm{b}}$ & $10.67^{\mathrm{b}}$ & 0.13 \\
Initial body weight (kg) & 8.23 & 8.06 & 8.31 & 0.03 \\
Slaughter weight $(\mathrm{kg})$ & $10.9^{\mathrm{b}}$ & $11.33^{\mathrm{a}}$ & $10.81^{\mathrm{b}}$ & 0.07 \\
Empty body weight $(\mathrm{kg})$ & $9.03^{\mathrm{b}}$ & $10.32^{\mathrm{a}}$ & $9.60^{\mathrm{b}}$ & 0.16 \\
Hot carcass weight $(\mathrm{kg})$ & $4.72^{\mathrm{b}}$ & $6.01^{\mathrm{a}}$ & $5.03^{\mathrm{b}}$ & 0.09 \\
Cold carcass weight $(\mathrm{kg})$ & $4.01^{\mathrm{b}}$ & $5.54^{\mathrm{a}}$ & $4.38^{\mathrm{b}}$ & 0.05 \\
Chilling losses (\%) & $15.04^{\mathrm{a}}$ & $7.82^{\mathrm{c}}$ & $12.92^{\mathrm{b}}$ & 0.18 \\
Hot carcass yield (\%) & $43.14^{\mathrm{b}}$ & $53.05^{\mathrm{a}}$ & $46.53^{\mathrm{b}}$ & 0.21 \\
Cold carcass yield (\%) & $36.66^{\mathrm{b}}$ & $48.90^{\mathrm{a}}$ & $40.52^{\mathrm{b}}$ & 0.19 \\
True yield (\%) & $52.27^{\mathrm{b}}$ & $58.24^{\mathrm{a}}$ & $52.40^{\mathrm{b}}$ & 0.04 \\
\hline
\end{tabular}

Av $=$ Average

a,b,c Means with different superscripts along the same row are significantly different $(\mathrm{P}<0.05)$. SEM $=$ standard error of means.

$\mathrm{A}=70 \%$ guinea grass $+30 \%$ concentrate diet. $\mathrm{B}=$ mixture of $50 \%$ Bambusa vulgaris leaves $+20 \%$ neem seed cake $+30 \%$ concentrate diet. $\mathrm{C}=$ combination of $45 \% \quad$ Bambusa vulgaris leaves $+25 \%$ neem seed cake $+30 \%$ concentrate diet.

Hot and cold carcass weight were lower in rams on diets $\mathrm{A}(4.72 \& 4.01 \mathrm{~kg})$ and $\mathrm{C}(5.03$ $\& 4.38 \mathrm{~kg})$ significantly $(\mathrm{P}<0.05)$ compared with diet B $(6.01 \& 5.54 \mathrm{~kg})$. The reduction in nutrient utilization especially in relation to levels of crude protein and energy for rams consuming diets $\mathrm{A}$ and $\mathrm{C}$ might explain the decrease observed for carcass weights; given the direct implication of these parameters on ram performance and that they are the natural makers of nutrient intake and utilization (Galvani et al., 2014). Chilling losses was significantly $(\mathrm{P}<0.05)$ lowest in rams on $\operatorname{diet} \mathrm{B}(7.82 \%)$ and highest in those on $\operatorname{diet} \mathrm{A}$ (15.04\%). Literature describes chilling loss as the weight difference after carcass cooling and it depends on several factors such as humidity loss and chemical reactions in the muscle (Elias et al., 2015). Improving carcass management, storage and fat subcutaneous disposition may likely 
decrease humidity loss and act as a thermal insulator for the body. Water losses are due to genetic effects, fat cover and its distribution (Lage et al., 2014). The variation in fat disposition between individual carcasses could likely explain the result of chilling losses noticed in this study. Notwithstanding, the values for hot and cold carcass yield were better in diet B (53.05 \& 48.90\%) than those on diets $C$ (46.53 \& 40.52\%) and $\mathrm{A}(43.14 \& 36.66 \%)$. The purpose of using alternative feeds in livestock diet is to provide all round feeds during the off-season with reduce cost and improve or at least not affect carcass variables and performance negatively (Elias et al., 2015). In the present study, using BVL with NSC as alternative feed ingredients has limited the choice of guinea grass that may short in production during the dry season and impact positively in most of the carcass characteristics examined. Moreover, result on diets A and C could be explained by the fact that carcass with similar weights and amount of fat means that all body areas are in similar proportions (Maciel et al., 2015). The true yield that ranged between $52.27 \%$ in diet $\mathrm{A}$ and $58.24 \%$ in diet B followed the same trend as observed in carcass yield. The interesting observation was that, the turned out of true yield corresponded to the weights and yield of carcass in this study, which further testify the influence of BVL with NSC in the treatment diets and their levels of nutrient utilization by rams for their performance.

Treatment diets had significant $(\mathrm{P}<0.05)$ effect on the liver and kidneys of noncarcass components, greater proportion of the liver and kidneys were found in rams on diet B $(2.01 \& 1.12 \%)$ compared with diets A $(1.66 \& 0.59 \%)$ and $C(1.87 \& 0.81 \%)$. This could probably be the turned out of high protein and energy nutrient of rams slaughtered at $11.33 \mathrm{~kg}$ of live weight (Table
2) that resulted in greater weights and faster accretion rates of liver and kidneys in rams on diet B. However, the maintenance of energy requirement can be attributed to the visceral organs, especially the liver and kidneys that were associated with the high rates of energy and protein syntheses in the tissue. Atti and Mohouachi (2011) found that mechanism involved in reducing total energy expenditure of liver and kidneys tissue may differ under condition of dietary protein and energy restriction. This is in corroboration with the report of Casey and Webb (2010) who noted that liver and kidney weights can be decreased with nutrient restrictions.

Tissues essential for life process (respiration and metabolism) will be expected to be highly developed at birth, whereas tissues associated with locomotion and storage would be lesser developed and tissues associated with reproduction would be among latest maturing tissues (Galvani et al., 2014). However, lungs had marked different rate in this study as expected because of their stage of development. Rams on diet B (1.35\%) had significant higher values for lungs than those in diets $\mathrm{A}$ $(0.72 \%)$ and $\mathrm{C}(0.98 \%)$. This disparity in weights of lungs could be attributed to the chemical composition of the BVL with NSC supplied at varying levels, mainly energy and protein content of the feed and the coarse nature of the guinea grass.

Heart and spleen that ranged from 0.51 to $0.55 \%$ and 0.16 to $0.24 \%$ respectively were not significantly $(\mathrm{P}>0.05)$ influenced by treatment diets. This could be as a result of these organs maintaining their integrity due to the priority of nutrient utilization and independently of feeding. This effect was also observed by Costa et al. (2013) who found no difference between treatments for heart and spleen weights when diets with different protein and energy sources and 


\section{Okoruwa, Okoh and Ikhimioya}

levels were used for feeding sheep. Advancement in the pre-stomachs is likely due to the type of feed consumed by the animals, considering that the rumen/reticulum volume is related to its function (nutrient fermentation). The more forage is added to the animal diet the greater is the rumen/reticulum size (Urbano et al., 2013). The higher significant difference (P $<0.05$ ) observed among rumen / reticulum of rams on diet A $(2.04 \%)$ compared with diets B (1.98\%) and C (1.96\%) could likely be due to the high dietary roughage proportion of the grass intake. However, this fore-gut difference corresponded with the result obtained in average total feed intake (Table 2). This observation further testifies to the influence of BVL with NSC compared with guinea grass on the type of feed intake in fore-gut sizes.

Table 3: Non-carcass components (\%) of the experimental rams fed Bambusa vulgaris leaves with neem seed cake and guinea grass.

\begin{tabular}{|c|c|c|c|c|}
\hline \multirow[b]{2}{*}{ Variables } & \multicolumn{3}{|c|}{ Diets } & \multirow[b]{2}{*}{ SEM \pm} \\
\hline & $\mathbf{A}$ & B & C & \\
\hline Liver & $1.66^{\mathrm{b}}$ & $2.01^{\mathrm{a}}$ & $1.87^{\mathrm{b}}$ & 0.02 \\
\hline Kidneys & $0.59^{\mathrm{b}}$ & $1.12^{\mathrm{a}}$ & $0.81^{\mathrm{b}}$ & 0.06 \\
\hline Lungs & $0.72^{\mathrm{b}}$ & $1.35^{\mathrm{a}}$ & $0.98^{\mathrm{b}}$ & 0.01 \\
\hline Heart & 0.51 & 0.55 & 0.53 & 0.04 \\
\hline Spleen & 0.17 & 0.24 & 0.16 & 0.07 \\
\hline Rumen/reticulum & $2.04^{\mathrm{a}}$ & $1.98^{\mathrm{b}}$ & $1.96^{\mathrm{b}}$ & 0.10 \\
\hline Omasum & 0.09 & 0.07 & 0.06 & 0.01 \\
\hline Abomasum & 0.15 & 0.13 & 0.14 & 0.13 \\
\hline Blood & 0.14 & 0.16 & 0.14 & 0.14 \\
\hline Skin & 2.18 & 2.18 & 2.17 & 0.09 \\
\hline Head & 4.92 & 4.90 & 4.91 & 1.02 \\
\hline
\end{tabular}

The weights of omasum and abomasum that ranged from 0.06 to $0.09 \%$ and 0.13 to $0.15 \%$ respectively did not differ $(\mathrm{P}>0.05)$ significantly between treatment diets. This could be due to the similar age of the rams which influenced that the hind-gut development were linked to the age and consequently not affected by the feeding trial. As for the by-products, the weight of the blood (0.14 to $1.16 \%$ ), skin (2.17 to $2.18 \%$ ) and head (4.90 to $4.92 \%$ ) did not differ $(\mathrm{P}>0.05)$ significantly between treatment diets. This non - significant values recorded among the by - products could probably be influenced by factors such as type of birth, genetics and age. Skin has been reported (Diaz et al., 2002) to be associated with the intrinsic equality of the ovine hind without wool, with greater strength and smoothness when converted into leather. Costa et al. (2013) also reported that when body follows a growth curve, the head is the first one to develop, followed by the trunk and finally the members.

\section{Conclusion}

Based on the result obtained from this study, it can therefore be concluded that the replacement of guinea grass with combination of Bambusa vulgaris leaves with neem seed cake in ram diets positively influenced the measured body weight at slaughter, carcass and non-carcass 
characteristics. However, the feeding of Bambusa vulgaris leaves that is available all year round with neem seed cake to rams, can justify the choice of guinea grass that is limited in production during the dry season. Hence, this can strategically reduce the stress of ruminant farmers looking for unavailable and high price alternative feeds to replace guinea grass in order to offset losses related to the carcass and non-carcass weight in rams during the dry season.

\section{References}

Antwi - Boasiako, C., Coffie, G. Y. and Darkwa, N. A. 2011. Proximate composition of the leaves of Bambusa ventricosa, oxytenanthera abyssinica and two varieties of Bambusa vulgaris. Scientific Research and Essays 6(3): $6835-6839$.

AOAC 1990. Official method of analysis, $15^{\text {th }}$ ed. Association of Official Analytical Chemical, Washington DC., USA.

Atti, N. and Mahouachi, M. 2011. The effects of diets, slaughter weight and docking on growth, carcass composition and meat quality of fat - tailed Babarine lambs, a review. Tropical Animal Health and Production 43: 1371-1378.

Bawa, G. S., Orumuyin, M., Agbaji, A. S., Ladan, Z. and Okekkeifi, U. O. 2006. Effect of different methods of processing Neem seeds on performance of young growing rabbits. Pakistan Journal of Nutrition 6: 212-2126.

Casey, N. H. and Webb, E. C. 2010. Managing goat production for meat quality. Small Ruminant Research 89: 218-224.

Costa, M. R. G. F., Pereira, E. S., Silva, A. M. A., Paulino, P. V. R.,
Mizubutie, I. V., Pimentel, P. G., Pinto A. P. and Rocha, J. N. 2013. Body composition and net energy and protein requirements of Morada Nova lambs. Small Ruminant Research 114: 206 213.

Diaz, M. T., Velasco, S., Caneque, V., Laurica, S., Ruiz de Huidobro, F., Perez, C., Gonzales, J. and Manzanares, C. 2002. Use of concentrate or pasture for fattening lambs and its effect on carcass and meat quality. Small Ruminant Reseaarch 43: 257-268.

Elias, A. K., Alves, K. S., Liberal Veras, R. M., Oliveira, L. R. S., Mezzomo, R., Curtrin, D. O. and Gomes, D. I. 2015. Caarcass and non-carcass characteristics of sheep fed with acai seed meal based diet. African Journal of Agricultural Research 10(49): 4395 - 4399.

Galvani, D. B., Pires, C. C., Hubner, C. H., Carhalho, S. and Wommer, T. P. 2014. Growth performance and carcass traits of early - weaned lambs as affected by the nutritional regimen of lactating ewes. Small Ruminant Research 120: 1-5.

Gowda, S. K. and Sastry, V. K. B. 2000. Neem (Azadirachta indica) seed cake in animal feeding - scope and limitations - review. Asian Australia Journal of Animal Scienc 13: $720-728$.

Lage, J. F., Paulno, P. V. R., Pereira, L. G. R., Duarte, M. S., Valadares Filho, S. C., Oliveira, A. S., Souza, N. K. P. and Lima, J. C. M. 2014. Carcass characteristics of feedlot lambs fed crude glycerin contaminanted with high concentrations of crude fat. 
Journal of Meat Science 96: 108 113.

Maciel, M. V., Carvaliho, F. F. R., Bastista, A. M. V., Guim, A., Souza, E. J. O., Marciel, L. P. A. A., Pereira-Neto, J. D. and LimaJunior, D. M. 2015. Carcass and non-carcass characteristics of sheep fed on cassva. (Manihot pseudoglaziovii Pax and K. Hoffm). Chilean Journal of Agricultural Research 75(3): 307-312.

Ogbuewu, I. P., Odoemenam, V. U., Obikaonu, H. O., Opera, M. N., Emenalom, O. O., Uchegbu, M., Okoli, I. C., Esonu, B. O. and Iloeje, M. U. 2011. The growing importance of Neem (Azadirachta indica) in Agriculture Industry, Medicine and Environment: A Review. Research Journal of Medical Plant 5(3): 230-245.

SAS, 1999. Statistical Analysis System, SAS User's Guide. Cary, NY: SAS Institute.
S k a p e t a s, B ., S i n a p is, E ., Hetziminaouglou, J., Karala A. and Katanos. J. 2006. Effcet of age at slaughter on carcass characteristics and carcass composition in lambs of mountain Greek breeds. Czech Journal of Animal Science 51(7): 311-317.

Urbano, S. A., Ferreira, M. A., Dutra Junior, W. M., Xavier de Andrade, R., Bernardo de Siqueira, M. C. and Felix, S. C. R. 2013. Coarcass characteristics of sheep fed with castor bean hulss in replacement of tyton 85 hay. Cienc Agrotechnological Lavras 36(1): $85-93$.

Zehui, J. 2007. Bamboo and rattan in the world. Chain forestry publishing house. $1^{\text {st }}$ ed. Beijing, China Pp. 360 .

Received: $24^{\text {th }}$ September, 2016 Accepted: $28^{\text {th }}$ January, 2017 